\title{
EKSISTENSI HUKUM ISLAM DAN HUKUM ADAT \\ DALAM SISTEM HUKUM NASIONAL
}

Oleh :

Abdurrahman Konoras

(abdurrahmankonoras@yahoo.com)

\begin{abstract}
Islamic Law and Customary Law is part of the national legal system in addition to some other legal systems that also give meaning and role. But as a system and legal system, Islamic Law and Customary Law show a clear separation.Thus, both are standing alone and independent. The continuing development of both shows which of them can continue to exist and which of them is increasingly left behind or even reduced in terms of role.
\end{abstract}

Keywords: Law System, Islamic Law, Customary Law.

\begin{abstract}
ABSTRAK
Hukum Islam dan Hukum Adat adalah bagian dari sistem hukum nasional disamping adapula sistem-sistem hukum lainnya yang turut memberi arti dan peran. Namun sebagai suatu sistem dan sistem hukum, Hukum Islam dan Hukum Adat menunjukan pemisahan sehingga berdiri sendiri dan mandiri, dan kelanjutan perkembangan kedua sistem hukum tersebut menunjukan sistem hukum mana yang dapat eksis dan mana yang dapat semakin tertinggal, bahkan berkurang peranannya.
\end{abstract}

Kata kunci : Sistem Hukum, Hukum Islam, Hukum Adat.

Jurnal Ilmiah Al-Syir'ah Vol. 14 No. 2 Tahun 2016

Institut Agama Islam Negeri (IAIN Manado) 


\section{PENDAHULUAN}

Ketika politik hukum kolonial menempatkan kedudukan Hukum Islam sebagai bagian dari Hukum Adat, dalam perkembangannya pasca-kemerdekaan Republik Indonesia bermunculan teori-teori yang membantah masunya Hukum Islam kedalam bagian Hukum Adat.

Politik hukum penguasa Indonesia pasca-kemerdekaan turut mendorong kenyataan yang berkembang, seperti penghapusan peradilan adat (adatrechspraak) secara berangsurangsur. Hapusnya pengadilan Adat telah merusak dan menggerus kekuatah hukum Adat sebagai suatu sistem hukum yang berlaku di Indonesia, sebaliknya Hukum Islam memperlihatkan penguatan peradilan agama yang terakhir ini diatur berdasarkan UU No. 50 Tahun 2009 tentang Perubahan Kedua atas UU No. 7 Tahun 1989 tentang Peradilan Agama.

Eksistensi Hukum Islam semakin menguat dengan berlakunya sejumlah peraturan perundang-undangan dalam bidang Surat Berharga Syariah Negara (SBSN) (Sukuk), Perbankan Syariah, Pengelolaan Haji, Pengelolaan Zakat, dan lain-lainnya, dan sebagai suatu sistem hukum, Hukum Islam yang mengusung nilai-nilai Islami (Prinsip-prinsip Syariah), semakin memberi arti dalam pola perilaku bermasyarakat, berbangsa, dan bernegara, meskipun secara konstitusional ditegaskan bahwa Negara Indonesia bukan Negara berdasarkan atas dasar Hukum Islam, namun dalam tataran implementatif, kedudukan dan peran Hukum Islam sebagai bagian dari sistem hukum nasional dihadapkan pada berbagai tantangan, apakah nantinya Hukum Islam, tetap eksis atau akan mengalami nasib yang sama seperti Hukum Adat, apalagi di era globalisasi dan menguatnya demokratisasi dan HAM yang membutuhkan jawaban terhadap berbagai masalah dan isu kontemporer. 


\section{PEMBAHASAN}

\subsection{Konsep dan Pengertian}

\subsubsection{Sistem dan Sistem Hukum}

Sistem (System, bahasa Inggris) senantiasa dikaitkan dengan adanya sejumlah bagian atau elemen, atau unsur sebagai suatu kesatuan.Bahkan, dikatakan pula sebagai suatu keseluruhan (whole). Kesatuan dan juga keseluruhan dari bagian atau elemen atau unit tersebut berhubungan atau berkaitan erat satu sama lain.

Arti 'Sistem' (System) itu sendiri dirumuskan oleh Black (Back, 1979), sebagai "Orderly combination or arrangement, as of particulars, parts, or elements into a whole". Schrode dan Voich (dalam Satjipto Rahardjo) merumuskan sistem itu sebagai suatu kesatuan yang kompleks, yang terdiri dari bagian-bagian yang behubungan satu sama lain (Rahardjo, 2006). Sedangkan Teori Sistem itu sendiri telah berkembang demikian menarik serta mendapat perhatian besar para pakar misalnya: Teori Analogi Organis (Organic Analogy), Teori Analitis Mekanis (Rasjidi dan Wyasa, 1993); Bahkan Niklas Luhman terkenal dengan pemikirannya tentang konsep Autopoietic yang merujuk pada diversitas (perbedaan) sistemsistem sel biologis sampai keseluruh masyarakat dunia. Luhman menggunakan istilah Autopoietic untuk merujuk pada sistem-sistem, antara lain ekonomi, politik, hukum, ilmu dan birokrasi (HS, 2010).

Suatu sistem memiliki ciri-ciri tertentu sebagai ciri-ciri sistem. Elias M. Awad (dalam Salman dan Susanto, 2004) mengemukakan ciri-ciri sistem, seperti:

1) Sistem itu bersifat terbuka, atau pada umumnya bersifat terbuka.suatu sistem dikatakan terbuka jika berinteraksi dengan lingkungannya, dan sebaliknya, dikatakan tertutup jika mengisolasikan diri dari pengaruh apapun;

2) Sistem terdiri dari dua atau lebih subsistem dan setiap subsistem terdiri lagi dari subsistem lebih kecil, begitu dan seterusnya;

3) Subsistem itu saling bergantung satu sama lain dan saling memerlukan; 
4) Sistem mempunyai kemampuan untuk mengatur diri sendiri (selft-regulation); dan

5) Sistem memiliki tujuan dan sasaran.

Dalam sistem terdapat lagi subsistem-subsistem, maka dalam bidang politik dikenal Sistem Politik (Indonesia), Sistem Pemerintahan, Sistem Pemilihan Umun (Pemilu), yang menurut Asshiddiqie (2007) kedua system pemilu yaitu sistem distrik dan sistem proporsional pada pokoknya sama-sama dianut dalam penyelenggaraan pemilu di Indonesia. Dalam bidang ekonomi dikenal antara lain Sistem Ekonomi Kapitalis, Sistem Ekonomi Sosialis, dan Sistem Ekonomi Islam (Ekonomi Syariah). Demikian pula dalam hukum dikenal antara lainnya Sistem Hukum Islam, Sistem Hukum Adat, Sistem Hukum Barat, dan lain-lainnya.

Hukum adalah suatu sistem sehingga disebut sebagai Sistem Hukum (Legal System). Sudikno Mertokusumo menjelaskan, pada hakikatnya sistem, termasuk sistem hukum merupakan suatu kesatuan hakiki dan terbagi dalam bagian-bagian, di dalam mana setiap masalah itu persoalan menemukan jawaban atau penyelesaiannya.Jawaban itu terdapat dalam sistem itu sendiri.Sebagai suatu sistem, maka di dalam hukum itu terdapat sistem (subsistem) (Mertokusumo, 2005).

C.F.G. Sunaryati Hartono (1991), menerangkan karena suatu sistem itu terdiri dari sejumlah unsur atau komponen yang saling berkaitan dengan saling pengaruh-mempengaruhi, lagi pula terikat oleh suatu atau beberapa asas tertentu,maka sistem hukum itu pun terdiri dari sejumlah unsur atau komponen, yang sebagian pada saat ini sudah ada dan sudah berfungsi, tetapi sebagian besar lagi masih harus diciptakan. Menurut Paul Scholten (dalam Achmad Ali, 2002), hukum sebagai suatu sistem, yang berarti semua aturan saling berkaitan, aturanaturan itu dapat disusun secara mantik, dan untuk yang bersifat khusus dapat dicarikan aturan-aturan umumnya.

Bertolak dari uraian tersebut, konsep sistem dan sistem hukum berpangkal dari hukum itu terdiri atas sejumlah bagian, elemen, atau unsur. Kemudian, terdapat kaitan atau hubungan yang erat satu sama lainnya. Bagian, elemen atau unsur yang saling berkaitan erat satu sama 
lainnya itu diikat oleh hukum, dan dalam hukum (sistem hukum) itu terdapat suatu tujuan yang hendak dicapai. Dari konsep itulah, maka Sudikno Mertokusumo (2005), menerangkan bahwa hukum sebagai sistem berarti merupakan tatanan, suatu kesatuan yang terdiri dari unsur-unsur yang mempunyai interaksi satu sama lain dan bekerjasama untuk mencapai tujuan kesatuan tersebut.

Dari konsep dan rumusan sistem dan sistem hukum di atas, di mana unsur pengingat di antara berbaga komponen, bagian atau unsur hukum? Satjipto Rahardjo menjawabnya, karena adanya ikatan oleh asas-asas hukum, maka hukum pun-merupakan satu sistem.Peraturan-peraturan hukum yang terdiri sendiri-sendiri itu lalu tarkait dalam satu susunan kesatuan disebabkan karena mereka bersumber pada satu induk penilaian etis tertentu (Rahardjo, 2006). Lebih lanjut dijelaskannya, apabila sekarang sampai pembicaraan mengenai asas hukum, maka pada saat itu kita membicarakan unsur yang penting dan pokok dari peraturan hukum.Barangkali tidak berlebihan apabila dikatakan, bahwa asas hukum ini merupakan 'jantungnya' peraturan hukum (Rahardjo, 2006).

Dalam peraturan perundang-undangan ditentukan sejumlah asasnya seperti asas Perbankan Syariah menurut UU No. 21 Tahun 2008 yang berasaskan Prinsip Syariah, demokrasi ekonomi, dan prinsip kehati-hatian (Pasal 2). Asas-asas dalam Pemilu Anggota DPR, DPD dan DPRD menurut UU No. 8 Tahun 2012 yakni asas langsung, umum, bebas, rahasia, jujur dan adil (Pasal 2). Namun pada dasarnya, asas termasuk asas hukum bukanlah peraturan hukum, akan tetapi hukum akan dapat dipahami dengan memahami asas-asasnya.

Para pakar membagi sistem-sistem hukum yang dikenal di dunia.Menurut Wayne R. Barnes (dalam Haula Adolf, 2007), sistem hukum yang banyak dipraktikkan di dunia ialah Civil Law dan Commom Law. Negara-negara yang mempraktikkan sistem hukum ini ada yang secara penuh (pure) serta yang campuran (mixed forms). Pakar lainnya, yakni Zweigert dan Kotz (dalam O.C. Kiligis) membagi 8 delapan sistem hokum di dunia yakni : the Romanic; the Germanic; the Anglo-American; the Nordic; the (Former) Socialist; the Eastern; the Hindu; the Islamic (Kaligis, 2006). Eric L. Richard (dalam Ade Maman 
Suherman, 2006), membagi sistem-sistem hukum utama (major legal systems) yang terdiri dari: Civil Law; Common Law; Customary Law; Islamic Law; Socialist Law; Sub-Saharan Africa; Par East.

Achmad Ali (2009), menggolongkan sistem-sistem hukum atas: Civil Law; Common Law; Customary Law; Muslim Law; dan Mixed Law.Achmad Ali lebih lanjut menerangkan, di Indonesia berlaku Mixed Law, di mana berlaku sistem hukum perundang-undangan, Hukum Adat, dan Hukum Islam.

\subsubsection{Hukum Islam dan Hukum Adat}

Bahwa Hukum Islam dan Hukum Adat merupakan bagian dari sistem hukum yang berlaku di Indonesia selain hukum perundang-undangan. Konsep Hukum Islam berbeda dari konsep hukum perundang-undangan, karena ajaran Islam meyakini hukum-hukumnya sebagai aturan yang bersumber dari wahyu Illahi, dan dengan demikian, hukum perundangundangan yang merupakan konsep hukum karya manusia memiliki ciri khas yang berbeda dari Hukum Islam.

Ditinjau secara etimologis dan terminologis tentang Hukum Islam, secara etimologis, 'hukum' berasal dari bahasa Arab yaitu 'Al-Hukm' yang berarti berhalangan.Sedangkan secara terminologis, merupakan pandangan tentang masalah tertentu yang terkait dengan tindakan atau perbuatan manusia.Hukum Islam dipandang sebagai bagian dari ajaran agama (Islam) yang norma-norma hukum (Islam) bersumber dari agama (Islam).Syamsu Anwar mengemukakan, umat Islam meyakini bahwa Hukum Islam berdasarkan kepada wahyu Illahi. Oleh karena itu, ia disebut syariah, yang berarti jalan yang digariskan Tuhan untuk manusia (Anwar, 2007).

Abd.Shomad, menjelaskan, karakteristik yang khas dari Hukum Islam yang membedakannya dari sistem hukum lainnya, di antaranya dalah hal sumber hukum yang mengenal dua macam sumber hukum.Pertama, sumber hukum yang bersifat 'Naqly', dan sumber hukum yang bersifat 'Aqly'.Sumber hukum 'Naqly' ialah Al-Qur'an dan As-Sunnah, 
sedangkan sumber hukum 'Aqly' ialah usaha menemukan hukum dengan mengutamakan olah pikir dengan beragam metodenya.Hukum Islam telah mendapat tempat penting dalam pembangunan hukum nasional jauh sebelum kemerdekaan Negara Republik Indonesia. Namun, ketika masa colonial, Hukum Islam untuk beberapa aspeknya ditempatkan sebagai bagian dari Hukum Adat:, sehingga dikenal di sejumlah masyarakat Hukum Adat seperti adat Gorontalo, adat Minangkabau, dan adat Bolaang Mongondow, ungkapan "Adat bersendi syara".

Perihal Hukum Adat (Adatrecht) adalah sistem hukum yang tumbuh dan berkembang dari kebiasaan-kebiasaan (customs) dalam masyarakat. R. Soepomo (1983), merumuskan, Hukum Adat adalah hukum non-statutior yang sebagian besar adalah hukum kebiasaan dan sebagian kecil Hukum Islam. Hukum Adat itu pun melingkupi hukum yang berdasarkan keputusan-keputusan hakim yang berisi asas-asas hukum dalam lingkungan, di mana ia memutuskan perkara. Berdasarkan rumusan ini, Hukum Adat adalah hukum tidak tertulis (non-statutior) yang sebagian besar adalah hukum kebiasaan dan sebagian kecil adalah Hukum Islam, dan diterapkan dalam peradilan adat (adatrechtspraak). Von Savigny (17991861) terkenal dengan tesisnya Volkgeist, bahwa semua hukum pada mulanya dibentuk dengan cara seperti yang dikatakan orang, hukum adat, dengan bahasa biasa. Hukum itu mulanya dibentuk oleh adat kebiasaan dan kepercayaan umum, kemudian oleh yurisprudensi (Friedmann, 1990).

Pada awal sejarah bangsa dan Negara Indonesia, Hukum Adat mendapatkan perhatian besar karena terdapat sejumlah pakar terkemukanya, yang secara konsisten memperjuangkan kedudukan Hukum Adat dalam sistem hukum nasional, antara lain ialah Moh. Koesnoe yang menyoroti salah paham terhadap kedudukan Hukum Adat dalam sistem hukum nasional di kalangan banyak pihak (pro-kontrak), bahwa dari kalangan yang kontra Hukum Adat berpendirian bahwa Hukum Adat berpaling ke belakang, kepada apa yang sudah lampau (Koesnoe, 1976). Soetandyo mengemukakan, percaturan politik dalam mewujudkan sistem hukum nasional dengan memperjuankan Hukum Adat, para penyongkong idenya sebenarnya 
terbilang pewaris ide tua, suatu ide yang sejak awal dikemukakan oleh nasionalis-nasionalis generasi pendahulu, bahkan juga sudah tertuang dalam naskah Sumpah Pemuda tahun 1928 (Widnjosoebroto, 1994).

Demikian pula politik hukum kolonial yang menempatkan kedudukan Hukum Islam sama dengan Hukum Adat, seperti teori Receptie oleh Christian Snouck Hurgronye, bahwa bagi rakyat pribumu pada dasarnya berlaku Hukum Adat; Hukum Islam berlaku jika norma Hukum Islam itu telah diterima oleh masyarakat sebagai Hukum Adat (Rahmat, 2006).

\subsection{Penyatuan dan Pemisahan Hukum Islam dan Hukum Adat}

Politik hukum kolonial yang menyatukan Hukum Islam ke dalam Hukum Adat (untuk aspek dan hal tertentu), sangat berperan dalam konsep dan rumusan-rumusan, hingga sekarang ini,, seperti dalam masyarakat adat Minangkabau, Gorontalo, dan Bolaang Mongondow dikenal ungkapan "Adat bersendi syara". Yang bermakna bahwa adat itu ditopang oleh Hukum Islam (Hukum Syar'i/Hukum Syara'). Sebagai politik hukum kolonial, terkait upaya penguasa kolonial untuk mengendalikan sistem hukum yang berlaku sekaligus menawarkan sistem hukum kolonial sebagai sumber hukum di wilayah jajahan,sebagaimana peran Hurgronye yang melahirkan Teori Receptie, artinya, Hukum Islam dapat diterima sebagai hukum apabila telah dilaksanakan oleh masyarakat adat, maka kemudian berlakulah Hukum Adat, seperti yang tertuang dalam Pasal 134 IS yang sering disebut Pasal Receptie (Rahmat, 2006).

Politik hukum kolonial yang menyatukan Hukum Islam dan Hukum Adat selain terumus dalam konsep dan beberapa teori produk pakar hukum kolonial, terus berlangsung hingga tercapainya kemerdekaan Negara Republik Indonesia, kemudian muncullah beberapa teori baru seperti yang dirumuskan oleh Sajuti Thalib dengan nama Teori Receptio a Contario bahwa: 1. Bagi orang Islam berlaku Hukum Islam; 2. Hal tersebut sesuai dengan keyakinan dan cita-cita hukum, cita-cita batin dan moralnya; dan 3. Hukum Adat berlaku bagi orang Islam jika tidak bertentangan dengan agama Islam dan Hukum Islam. Teori ini 
disebut dengan nama 'receptio a contrario' karena memuat teori tentang kebalikan (contra) dari Teori Receptio (Rahmat, 2006).

Dengan demikian, upaya hukum untuk memisahkan kedudukan dan peran Hukum Islam dari Hukum Adat semakin jelas dan terarah.

Pada masa penguasaan kolonial di Hindia Belanda, bersamaan pula dengan masuknya sistem hukum Eropa Kontinental (Civil Law System) sebagaimana dianut dan diterapkan di Negara Belanda, kemudian diadopsi di wilayah jajahannya di Hindia Belanda yang antara lainnya dalam bentuk Burgerlijk Wetboek (BW), Wetboek van Koophandel (WvK.), Wetboek van Strafrecht (WvS) sebagai kitab-kitab kodifikasi yang bercorank peraturan perundang-undangan dan mengusung aspek kepastian hukum.

Sebagai hukum yang sebagian besar tidak tertulis, maka Hukum Adat yang semula dikonsepsikan bersama dengan Hukum Islam juga berhadapan dengan kuatnya sistem perundang-undangan sebagai sistem hukum yang berlaku. Hukum Adat yang sebagian besar tidak tertulis, berhadapan dengan sistem hukum perundang-undangan yang bersifat tertulis, dan kenyataannya hingga pasca-kemerdekaan Indonesia, produk hukum kolonial sebagai warisan hukum Belanda, terus berlaku sebagai sumber hukum dalam tata hukum di Indonesia berdasarkan asas konkordansi.

\subsection{Eksistensi Hukum Islam dan Hukum Adat}

Kedua sistem hukum di Indonesia tersebut saling pengaruh-mempengaruhi yang menunjukkan sebagai sistem terbuka, namun dalam perkembangannya terjadi penggerusan dan pelemahan terhadap kedudukan Hukum Adat sebagai suatu sistem hukum baik terhadap substansi hukumnya maupun terhadap struktur hukumnya.Sedangkan pada Hukum Islam terjadi justru sebaliknya, dan Hukum Islam semakin mempersiapkan dan melengkapi dengan berbagai substansi hukum maupun struktur hukumnya.

Suatu sistem hukum senantiasa terdapat tiga unsur atau komponennya menurut Lawrence M. Friedman (dalam Achmad Ali, 2009), yakni unsur struktur hukum, substansi 
hukum dan kultur hukum. Dalam Hukum Adat, bagian dari substansi hukumnya seperti penghapusan pengadilan adat dan dengan demikian penghapusan pula terhadap struktur hukumnya, telah berlangsung pasca-kemerdekaan Indonesia. Padahal, putusan-putusan pengadilan adat menjadi bagian penopang eksistensi Hukum Adat.

Ketika berlakunya UU No. 14 Tahun 1970 tentang Pokok-Pokok Kekuasaan Kehakiman, ditentukan penghapusan peradilan adat dalam Pasal 39, dan berdasarkan penjelasan atas Pasal 39 ini disebutkan bahwa berdasarkan pada UU No. 1 Drt. Tahun 1961 tentang tindakan sementara untuk Menyelenggarakan Kesatuan, Susunan, Kekuasaan dan Acara Peradilan, Sipil, pada Pasal 1 ayat (2) oleh Menteri Kehakiman secara berangsurangsur telah menghapuskan Pengadilan Adat/Swapraja di seluruh Bali, Sulawesi, Lombok, Sumbawa, Timor, Kalimantan dan Jambi. Dengan Peraturan Presiden No. 6 Tahun 1966 tentang Penghapusan.Pengadilan Adat/Swapraja dan Pembentukan Pengadilan Negara di Irian Barat.Peraturan Presiden tersebut berdasarkan UU No. 5 Tahun 1969 telah ditingkatkan menjadi UU.

Hukum Islam justru sebaliknya. Ketika Pengadilan Adat tidak dikenal sekarang ini sebagai bagian dari sistem peradilan nasional, maka Hukum Islam, khususnya melalui Peradilan Agama telah diberikan landasan konstitusional berdasarkan Undang-Undang Dasar Negara Republik Indonesia Tahun 1945 sebagai salah satu lingkungan peradilan (Pasal 24 ayat (2)). Ketentuan konstitusional yang menunjukkan dasar hukum Peradilan Agama tersebut kemudian diturunkan dalam Pasal 18 UU No. 48 Tahun 2009 tentang Kekuasaan Kehakiman, dan diatur dengan UU No. 50 Tahun 2009 tentang Perubahan Kedua atas UU No. 7 Tahun 1989 tentang Peradilan Agama, serta menentukan bahwa Peradilan Agama adalah peradilan negara.

Justru penguatan Peradilan Agama sebagai sistem hukum di Indonesia semakin bertambah dengan adanya sejumlah peraturan perundang-undangan yang mendukung dan memperkuat kewenangan Peradilan Agama, antara lain dalam Pengelolaan Zakat, 
Pengelolaan Haji, Perbankan Syariah, Surat Berharga Syariah Negara (SBSN) (Sukuk), yang memperlihatkan suatu formalisasi Hukum Islam ke dalam Hukum Perundang-undangan.

Pengaruh sistem hukum Eropa Kontinental (Civil Law) melalui sistem hukum Indonesia menunjukkan ciri posotivistik yang mampu diterima dan diterapkan dalam sistem Huku Islam melalui formalisasi Hukum Islam. Sementara itu, sistem Hukum Adat yang juga diatur dan dikembangkan lebih lanjut dari hukum perundang-undangan, justru memperlihatkan kontroversi seperti pengakuan hak masyarakat adat khususnya hak ulayat dalam UU No. 41 Tahun 1999 tentang Kehutanan jo UU No. 19 Tahun 2004 tentang Kehutanan, karenahak ulayat masyarakat adat sebenarnya telah hilang dan upaya mengembalikannya bukanlah suatu hal yang mudah.

Sistem Hukum Adat juga menunjukkan gradasinya, dari semula Hukum Adat ke Hukum Kebiasaan, akhirnya hanya menjadi adat-istiadat (adat-kebiasaan) yang ditemukan dalam praktik-praktik perkawinan adat, pakaian adat, dan lain-lainnya, yang sekedar upaya mengembalikan jatidiri agar eksistensi Hukum Adat masih ditemukan dalam masyarakat dan sistem hukum nasional.

\section{PENUTUP}

Sistem hukum nasional dibangun atas dasar Sisteh Hukum Islam, Sistem Hukum Adat, dan Sistem Hukum Barat, yang belakangan ini meningkat pula pengaruh Sistem Common Law sejalan dengan era globalisasi dan liberalisasi. Sistem-sisteh Hukum sebagai Sistem Hukum Nasional tersebut telah saling berjuang untuk tampil eksis dan memberi arti dalam pembentukan hukum nasional.

Walaupun demikian, dibandingkan Hukum Adat, maka Hukum Islam lebih mampu menunjukkan eksistensinya, mampu menerima masukan dan berkolaborasi dengan hukum perundang-undangan.Oleh karena itu, upaya untuk meningkatkan eksistensi Hukum Adat hendaknya perlu ditinjau kembali politik hukum yang tidak menunjukkan kemauan politik (political will) yang baik. 


\section{DAFTAR PUSTAKA}

Adolf, Huala, 2007. Dasar-Dasar Hukum Kontrak Internasional, Refika Aditama, Bandung.

Ali, Achmad, 2002. Menguak Tabir Hukum (Suatu Kajian Filosofis dan Sosiologis), Haji Masagung, Jakarta.

2009. Menguak Teori Hukum (Legal Theory) dan Teori Peradilan (Judicialprudence)

Termasuk Interpretasi Undang-Undang (Legisprudence), Kencana, Jakarta.

Anwar, Syamsul, 2007. Hukum Perjanjian Syariah, RajaGrafindo Persada, Jakarta.

Asshiddiqie, Jimly, 2007. Pokok-Pokok Hukum Tata Negara Republik Indonesia Pasca Reformasi, Bhuana Ilmu Populer, Jakarta.

Black, Henry Campbell, 1979. Back's Law Dictionary, West Publishing Co.

Friedmann, W, 1990. Teori dan Filsafat Hukum (Susunan II), Saduran Mohammad Arifin, Rajawali Pers, Jakarta.

Hartono, Sunaryati, C.F.G., 1991. Politik Hukum Menuju Satu Sistem Hukum Nasional, Alumni, Bandung.

HS, Salim, 2010. Perkembangan Teori dalam Ilmu Hukum, RajaGrafindo Persada, Jakarta.

Kaligis, Moh., 2006. Perlindungan Hukum Atas Hak Asasi Tersangka, Terdakwa, dan Terpidana, Alumni, Bandung.

Koesnoe, Moh., 1976. Perkembangan Hukum Adat Setelah Perang Dunia II dalam Rangka Pembaharuan Hukum Nasional, Simposium Sejarah Hukum, Binacipta, Bandung.

Mertokusumo, Sudikno, 2005. Mengenal Hukum, Suatu Pengantar, Liberty, Yogyakarta.

Rahardjo, Satjipto, 2006. Ilmu Hukum, Citra Aditya Bakti, Bandung. 
Rahmat Rosyadi, A, dan Ahmad, M. Rais, 2006. Formalisasi Syariat Islam Dalam Perspektif Tata Hukum Indonesia, Ghalia Indonesia, Jakarta.

Rasjidi, Lili, dan Wyasa Putra, I.B, 1993. Hukum Sebagai Suatu Sistem, Remaja Rosdakarya, Bandung.

Salman S, HR. Otje dan Susanto, Anthon E, 2004. Teori Hukum (Mengingat, Mengumpulkan dan membuka kembali), Refika Aditama, Bandung.

Soepomo, R., 1993. Bab-Bab Tentang Hukum Adat, Pradnya Paramita, Jakarta.

Suherman, Ade Maman, 1993. Pengantar Perbandingan Sistem Hukum (Civil Law, Common Law, Hukum Islam), RajaGrafindo Persada, Jakarta.

Widnjosoebroto, Soetandyo, 1994. Dari Hukum Kolonial ke Hukum Nasional. Dinamika Sosial Politik dalam Perkembangan Hukum di Indonesia, RajaGrafindo Pesada, Jakarta. 